\title{
COMENTÁRIOS SOBRE A LEI FEDERAL INSTITUIDORA DAS PARCERIAS PÚBLICAS E PRIVADAS
}

\author{
COMMENTS ON THE FEDERAL LAW FOUNDING PUBLIC AND PRIVATE \\ PARTNERSHIPS
}

Rocco Antonio Rangel Rosso Nelson ${ }^{1}$

Isabel Cristina Amaral de Sousa Rosso Nelson²

Natasha Rangel Rosso Nelson ${ }^{3}$

\begin{abstract}
RESUMO: Afere-se a necessidade premente do Estado contemporâneo em renovar sua infraestrutura e constatado a insuficiência do orçamento público, vem o mesmo se socorrer do "mercado". Entretanto, no Brasil, a formação de contratos administrativos veiculados na Lei $\mathrm{n}^{\circ} 8.666 / 93$ e na Lei $\mathrm{n}^{\mathrm{o}} 8.987 / 95$, transfere-se todos os custos e responsabilidade para a entidade privada, não gerando o interesse para que os partícipes do "mercado" venham a investir nas obras e serviços públicos tão almejados pela sociedade. A pesquisa em tela, fazendo uso de uma metodologia de análise qualitativa, usando-se os métodos de abordagem hipotético-dedutivos de caráter descritivo e analítico, tem por linha de fundo analisar a Lei ${ }^{\circ}$ 11.079 de 2004, a qual institui normas gerais para licitação e contratação de parceria públicoprivada no âmbito da administração pública, introduzindo ao ordenamento brasileiro uma nova formatação contratual administrativa, com o intuito de cultivar o interesse de parceiros privados nos urgentíssimos projetos de infraestrutura.
\end{abstract}

PALAVRAS-CHAVE: Contratos Administrativos. Parceria Pública-Privada. Instrumento. Direito a infraestrutura.

ABSTRACT: Assesses the pressing need of the contemporary State to renew their infrastructure and noted the failure of the public budget, even if help comes from the "market". However, in Brazil, the formation of administrative contracts, published at Law 8.666/93 and Law $\mathrm{n}^{\circ}$ 8.987/95, which moves all costs and responsibility for the private entity does not generate interest for the partaker of the "market " will invest in public works and services as desired by society. Research on screen, making use of a method of qualitative analysis, using the methods of hypothetical-deductive approach of descriptive and analytical character, is the bottom line to analyze Law $n^{\circ} 11.079$ of 2004 . This establishes general rules for the bidding and hiring of public-private partnership within the public administration,

\footnotetext{
${ }^{1}$ Instituto Federal do Rio Grande do Norte - IFRN. Mestre em Direito Constitucional pela Universidade Federal do Rio Grande do Norte (2009) E-mail: rocconelson@hotmail.com

2 Centro Universitário FACEX. Possui graduação em Enfermagem pela Universidade Estadual da Paraíba (2000) Licenciatura plena em enfermagem. Especialização em Formação Profissional na Área de Saúde (Fiocruz/UFRN), Saúde da Família( Universidade Castelo Branco) e em Enfermagem do Trabalho( Facisa), Educação, desenvolvimento e politicas educativas( FIP)E-mail: isacristas@yahoo.com.br

${ }^{3}$ Bacharela em direito pela Universidade Federal do Rio Grande do Norte - UFRN. Advogada militante. Ex-Procuradora do Município de Lagoa de Pedra/RN. Atual Procuradora do Município de Boa Saúde/RN.Email: natasharosso@hotmail.com

- $\quad$ Artigo recebido em 06/07/2015 e aprovado para publicação em 18/02/1027
} 
introducing the Brazilian land a new contract administrative formatting in order to cultivate the interest of private partners in urgent infrastructure projects.

KEYWORD: Administrative Contracts. Public-Private Partnership. Instrument. Right infrastructure.

\section{CONSIDERAÇÕES INICIAIS}

O estudo, ora proposto, destina-se a analisar a dinâmica normativa que cunha a figura das parceiras públicas-privadas, ${ }^{4}$ no ordenamento jurídico brasileiro, introduzido pela prescrição redacional da Lei $\mathrm{n}^{\mathrm{o}} 11.079$ de 2004, a qual fora consectário da reforma da administração pública e da reforma fiscal. ${ }^{5}$

Neste contexto, são desenhadas as parceiras públicas-privadas no Brasil, tendo por fundo um Estado, o qual pleiteia uma administração gerencial em oposição à administração burocrática, ${ }^{6}$ possuindo esta como característica basilar o formalismo excessivo, constituindose um fim em si mesmo. Em contrapartida, o gerencialismo foca em metas, resultados, formas de controles e padrões de eficiência, dando maleabilidade, de forma a atingir a finalidade almejada, com o melhor custo-benefício.

Doravante, pare-passo a uma reforma administrativa baseada na eficiência como axioma, torna-se necessário uma reforma fiscal, com a finalidade de equilibrar o déficit público, sendo a Lei de Responsabilidade Fiscal (Lei complementar $\mathrm{n}^{\mathrm{o}} 101$ ) o "divisor de águas", a qual constituiu normas sobre o gerenciamento do endividamento e transparência nos gastos públicos. ${ }^{7}$

No presente estágio de desenvolvimento estatal (transição de um Estado interventor para um Estado Regulador) é fato que o orçamento público não permite que a administração

\footnotetext{
${ }^{4} \mathrm{O}$ professor Gustavo Binenbojm chama a atenção ao fato de que até a publicação da Lei $\mathrm{n}^{\mathrm{o}}$ 11.079/04 a expressão parceira pública e privada era utilizado de forma indiscriminada para indicar os mais avariados vínculos negociais entre a administração pública e a entidade privada, como aquelas fruto das concessões e permissões de serviços público (Lei $\mathrm{n}^{\circ}$ 8.987/95), contratos de gestão das organizações sociais, termos de parcerias das organizações sociais civil de interesse público, dentre outros. (Cf. BINENBOJM, Gustavo. As Parcerias Público-Privadas (PPPs) e a Constituição. Revista Eletrônica de Direito Administrativo Econômico, Salvador, Instituto de Direito Público da Bahia, $\mathrm{n}^{\circ}$ 2, maio-jun-jul, 2005. Disponível na Internet: <http:www.direitodoestado.com.br>. Acesso em: 18 de dezembro de 2013, p. 02).

${ }^{5}$ Cf. NÓBREGA, Marcos. Direito da Infraestrutura. São Paulo, Quartier Latin, 2011, p. 24.

${ }^{6}$ No Brasil se deu, principalmente, com a Emenda Constitucional no 19, de 04 de junho de 1998. Busca superar o paradigma do modelo burocrático de administração pública para o modelo gerencial, cujo cerne estava inovação, flexibilidade, resultado e eficiência. Mais detalhes em: NÓBREGA, Marcos. Direito da Infraestrutura. São Paulo, Quartier Latin, 2011, ps. 32-34.

${ }^{7}$ NÓBREGA, Marcos. Direito da Infraestrutura. São Paulo, Quartier Latin, 2011, p. 41/43.
} 
pública, exclusivamente, seja a responsável pelos gastos em infraestrutura, ${ }^{89}$ os quais são extremamente vultosos, de capital fixo duradouro, muitos sem retorno financeiro, outros de retorno em longíssimo prazo, tendo o objeto a característica da imobilidade e elevada especificidade. $^{10}$

Todavia, tais reformas, no que tange a essa infraestrutura ${ }^{11}$ são imprescindíveis para o crescimento e expansão do desenvolvimento no Brasil ${ }^{12}$ e consequentemente para que a

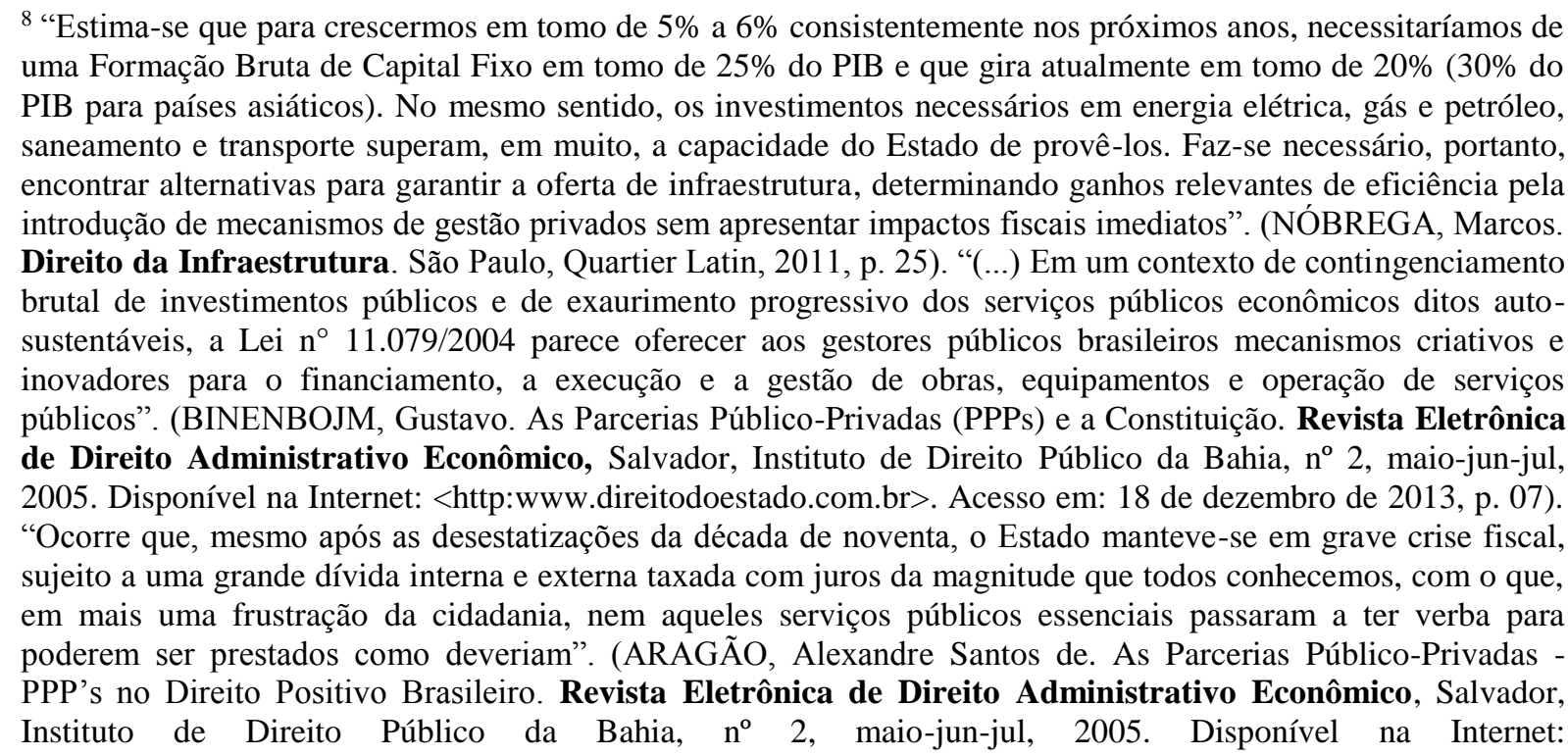
〈http:www.direitodoestado.com.br〉. Acesso em: 18 de dezembro de 2013, p. 02).

9 “(...) Com o alegado esgotamento do padrão de financiamento por parte do setor público, assiste-se a uma crescente retirada do Estado da produção direta de utilidade públicas. Tal conjuntura parece ser irreversível (...)." (SILVA, Roberta Cruz da. Entre o endeusamento e a descrença: a perigosa visão dicotômica sobre o contrato de parceria pública-privada na seara administrativa brasileira. IN: Revista brasileira de direito administrativo e regulatório. São Paulo: Editora MP, V. 4, 2011, p. 179).

10 "Quanto maior for a especificidade, a peculiaridade do ativo empregado, maior a possibilidade do surgimento de quase renda, ou seja, a diferença de retorno da aplicação do ativo naquela atividade ou em qualquer outra atividade. Da mesma forma, quanto maior for essa especificidade, mais o contrato e o contratante se relacionarão de forma exclusiva ou quase exclusiva. Existem vários tipos de especificidade de ativos que precisam ser considerados. O primeiro deles trata da especificidade referente à localização do ativo (site specificity), ou seja, alguns ativos devem ser alocados em áreas preestabelecidas, considerando as facilidades de transporte, comunicação e custo dos insumos. Outro tipo seria a especificidade de tempo, que caracterizaria a sincronia do processo produtivo para a economia de custos. Outras especificidades importantes seriam os ativos fixos específicos e os ativos dedicados (complementares). O primeiro caso ocorreria quando, diante de características próprias das transações realizadas, os ativos não encontrassem usos alternativos ou viáveis, enquanto os ativos dedicados representam todos os insumos (não necessariamente ativos fixos) que são utilizados de forma única para aquela relação contratual e que possuem pouco ou nenhum uso alternativo. Por fim, temos também a especificidade que surge do processo contínuo de uso e aprendizado (human-asset specificity)". (NÓBREGA, Marcos. Análise econômica do Direito Administrativo. IN: TIMM, Luciano (org.). Direito e economia no Brasil. São Paulo. Atlas: 2011, ps. 412-413).

11 "Em numerosos países em desenvolvimento, as bases infraestruturais são incipientes e débeis, representando um entrave e uma séria condicionante dos esforços gizados em prol do crescimento económico. Por seu turno, nas nações mais desenvolvidas assiste-se à necessidade de redimensionamento e renovação do parque infraestrutural, que mostram sinais de acentuada deterioração e declino físico após décadas de subinvestimento nas infraestruturas económicas e sociais por parte das autoridades públicas". (AZEVEDO, Maria Eduarda. Parcerias Público-Privadas: instrumento de uma nova governança pública. 2008. Tese para obtenção do título de Doutora em Direito - Faculdade de Direito de Lisboa, p. 15) 
constelação de direitos cunhados como fundamentais, pela Constituição de 1988, sejam implementados, desenvolvidos e continuados.

Ponderar sobre as parceiras públicas-privadas é vislumbrar uma técnica jurídica promotora desse processo de renovação das infraestruturas, podendo-se falar em "Direito da Infraestrutura", ${ }^{13}$ o qual tornar-se-ia corolário ao direito ao desenvolvimento, ${ }^{14}$ um dos objetivos fundamentais da República Federativa do Brasil.

Assim, as PPP's configuram uma via alternativa exequível e abrangente que, de forma paradigmática, está ao dispor do decisor público para mobilizar as capacidades de financiamento e gestão do sector privado e fomentar a contestabilidade, franqueando a operadores privados a participação na esfera da prestação pública. ${ }^{15}$

As parcerias público-privadas surgem como uma tentativa de Estado e iniciativa privada dividirem os custos com a implantação de infra-estruturas, já que nenhum deles teria condições de com elas arcar individualmente: o Estado por não ter condições financeiras, e a iniciativa privada porque a tarifa seria insuficiente (ou em alguns casos até inexistente) para cobrir todos os seus custos e a legítima margem de lucro do negócio. ${ }^{16}$

No que tange ao argumento do uso das parceiras públicas-privadas como forma de socorrer o Estado, tendo em vista sua incapacidade financeira, sobreleva a crítica de do professor Celso Antonio Bandeira de Mello:

12 “(...)O Brasil padece de uma doença que vai se tornando crônica que é a sua incapacidade de suprir as demandas sociais cada vez maiores, por absoluta falta de recursos (...)”. (ALVARENGA, José Eduardo. Parcerias Público-Privadas: breves comentários. Revista Eletrônica de Direito Administrativo Econômico, Salvador, Instituto de Direito Público da Bahia, $\mathrm{n}^{\circ}$ 2, maio-jun-jul, 2005. Disponível na Internet: <http:www.direitodoestado.com.br>. Acesso em: 18 de dezembro de 2013, p. 06)

13 Sobre a terminologia "Direito da Infraestrutura ver a obra de: NÓBREGA, Marcos. Direito da Infraestrutura. São Paulo, Quartier Latin, 2011. “O problema hoje é que, para essa crise fiscal ser pelo menos mitigada, o País tem que crescer, e, para tanto, precisa reformar e ampliar a sua infraestrutura, para o que, no entanto, continua sem os recursos suficientes e com a capacidade de endividamento esgotada. Busca-se uma saída para esse impasse: para crescer e sair da crise financeira o Estado tem que investir em infraestrutura, mas não tem como financeiramente realizar tais investimentos". (ARAGÃO, Alexandre Santos de. As Parcerias Público-Privadas - PPP's no Direito Positivo Brasileiro. Revista Eletrônica de Direito Administrativo Econômico, Salvador, Instituto de Direito Público da Bahia, $n^{\circ}$ 2, maio-jun-jul, 2005. Disponível na Internet: <http:www.direitodoestado.com.br>. Acesso em: 18 de dezembro de 2013, p. 02).

14 “(...) o desenvolvimento que se pleiteia é aquele que proporciona uma efetiva mudança social, ou seja, a transformação para um grau determinado de mudança de atitudes, normas, instituições e comportamentos que estruturam a vida jurídica cotidiana, e que abrange não somente os novos modelos culturais, arranjos institucionais e disposições psicológicas, enfim que priorize uma revolução ética nas prioridades e melhorias materiais nas condições de existência e dignidade dos seres humanos. (...)”. (CASTRO JR, Osvaldo Agripino de. Breves considerações sobre o direito e desenvolvimento e sua relevância para a consolidação da justiça social e da cidadania no Brasil. Arquivo digital, p. 17).

${ }^{15}$ AZEVEDO, Maria Eduarda. Parcerias Público-Privadas: instrumento de uma nova governança pública. 2008. Tese para obtenção do título de Doutora em Direito - Faculdade de Direito de Lisboa, p. 15

16 ARAGÃO, Alexandre Santos de. As Parcerias Público-Privadas - PPP's no Direito Positivo Brasileiro. Revista Eletrônica de Direito Administrativo Econômico, Salvador, Instituto de Direito Público da Bahia, $\mathrm{n}^{\circ}$ 2, maio-jun-jul, 2005. Disponível na Internet: 〈http:www.direitodoestado.com.br>. Acesso em: 18 de dezembro de 2013, p. 02. 
Curiosamente, embora a concessão de serviços públicos clássica seja adotada para poupar investimentos públicos ou para acudir à carência deles, e esta última razão sempre foi a habitualmente apontada, entre nós, como justificativa para a introdução das PPPs, a lei pressupõe que na modalidade patrocinada a contraprestação pecuniária a ser desembolsado pelo Poder Público poderá "corresponder a até $70 \%$ da remuneração do contratado ou mais que isto, se houver autorização legislativa (art. 10, § $3^{\circ}$ ). Logo, é possível, de direito, que alcance qualquer porcentual, desde que inferior a $100 \%$. Seguramente, este não é um modo de acudir à carência de recursos públicos; antes, pressupõe que existam disponíveis e implica permissão legal para que sejam despendidos: exatamente a antítese das justificativas apontadas para exaltar este novo instituto. ${ }^{17}$

Essa contradição também não escapou ao crivo da professora Maria Zanella Di Pietro.

Verifica-se um verdadeiro paradoxo, pois se a Lei $\mathrm{n}^{\circ} 11.079 / 04$ foi criada para alavancar, principalmente, as obras de infraestrutura face o Estado não possuir aportes financeiros, como esse mesmo Estado falido vai custear até $70 \%$ da contratação e ofertar as mais diversas garantias previstas no dispositivo legal supra?

$\mathrm{Na}$ realidade, um dos principais objetivos declarados pelo governo e insistentemente aceito e comentado pela mídia é o que diz respeito à necessidade de realização de obras de infraestrutura, para as quais o governo não dispõe de recursos suficientes. Esse objetivo pode ser verdadeiro, mas é desmentido pelo fato de que a lei aprovada (Lei n 11.079 , de 30-12-2004) prevê duas modalidades de parceria - a concessão patrocinada e a concessão administrativa - em que a forma de remuneração abrange, total ou parcialmente, a contribuição pecuniária do poder público. (...) Além disso, embora o particular tenha que assumir a execução da obra (quando for o caso), por sua própria conta, o poder público terá que prestar pesadas garantias previstas na lei e dividir os riscos do empreendimento com o contratado nos casos de ocorrência de áleas extraordinárias, o que permite falar em compartilhamento dos riscos e gera certo paradoxo, porque se o poder público não dispõe de recursos para realizar as obras, dificilmente disporá de recursos para garantir o parceiro privado de forma adequada. ${ }^{18}$

É válido ressaltar que, as parcerias públicas e privadas não são uma forma de privatização, mas sim fruto de um processo evolutivo, o qual teve início com as

\footnotetext{
${ }^{17}$ MELLO, Celso Antônio Bandeira de. Curso de direito administrativo. 27 ed. São Paulo: Malheiros Editora, 2010, p. 775.

${ }^{18}$ DI PIETRO, Maria Sylvia Zanella. Parcerias na administração pública. $9^{\circ}$ ed. São Paulo: Editora Atlas, 2012, p. 146. "Se não houvesse a limitação inserida no artigo 22 da Lei n$^{\circ} 11.079$ e uma limitação natural decorrente da insuficiência de recursos financeiros para essas parcerias, poder-se-ia prever uma privatização em massa da Administração Pública e restaria a indagação: será que são desnecessárias (e, por isso mesmo, passíveis de se tornarem obsoletas) as normas constitucionais que estabelecem um regime jurídico público para a Administração Pública, exatamente para proteger o patrimônio público, a função administrativa do Estado e, acima de tudo, o interesse da coletividade?". (DI PIETRO, Maria Sylvia Zanella. Parcerias na administração pública. $9^{\circ}$ ed. São Paulo: Editora Atlas, 2012, p. 147).
} 
privatizações. ${ }^{19}$ Estas seriam a venda dos ativos públicos a entidades privadas e, consequentemente, o afastamento da intervenção e controle do Estado, no que se refere àquele setor, alocando todos os riscos ao setor privado.

As parcerias públicas e privadas se configuram de maneira diversa. O Estado não se abstém, pelo contrário, continua a intervir, a controlar aquele setor de interesse público, ${ }^{20}$ todavia, tem a entidade privada como parceira na construção de uma obra ou prestação de um serviço público, ${ }^{21}$ com maior eficiência, ${ }^{22}$ onde há um compartilhamento de riscos entre a entidade governamental e o parceiro privado. ${ }^{23}$

Em que pese as parcerias públicas e privadas, tecnicamente, não serem uma forma de privatização, não há como negar que, há um processo de transferência de funções públicas para as entidades privadas. É nesses termos as palavras da professora Maria Zanella Di Pietro:

Outro objetivo das parcerias público-privadas, menos declarado, mas também verdadeiro, é o de privatizar a Administração Pública, transferindo para a iniciativa privada grande parte das funções administrativas do Estado, sejam ou não passíveis de cobrança de tarifa dos usuários. Esse objetivo é inafastável de um outro, presente em toda a Reforma do Aparelhamento Administrativo do Estado, de fuga do direito administrativo, já que, sendo as atividades prestadas por empresas privadas, muitos dos institutos próprios desse ramo do direito não precisarão ser utilizados, como a licitação, os

\footnotetext{
19 “As PPPS, portanto, se inserem num processo de evolução que se iniciou com as privatizações, prosseguiu com a outorga de concessões de serviço público e de serviço público precedida da execução pública (chamadas concessões comuns pela Lei n. 11.079, de 30 de dezembro de 2004 - Lei das PPPs), disciplinadas pelo Estatuto Geral das Concessões (Lei n. 8.987 de 13.02.1995) e por diplomas legislativos pertinentes a setores específicos para desenvolvimento de projetos de infraestrutura e culmina com um marco legal aplicável às parcerias públicoprivadas, tendo entre seus objetivos fundamentais o de superar os sérios problemas de infraestrutura no Brasil num contexto de aperto fiscal e de baixa disponibilidade de recursos. Nessa trilha caminham Estados e Municípios”. GROTTI, Dinora Adelaide Musetti. Parcerias na administração pública. IN: Revista brasileira de direito administrativo e regulatório. São Paulo: Editora MP, V. 5, 2012, ps. 78-79.

${ }^{20}$ Cf. SILVA, Roberta Cruz da. Entre o endeusamento e a descrença: a perigosa visão dicotômica sobre o contrato de parceria pública-privada na seara administrativa brasileira. IN: Revista brasileira de direito administrativo e regulatório. São Paulo: Editora MP, V. 4, 2011, p. 185.

${ }^{21}$ Não só as parcerias públicas e privadas tem a sua aplicação no campo dos serviços públicos, como nas atividades de relevância publica, nos serviços sociais e culturais. (Cf. MODESTO, Paulo. Reforma do Estado, Formas de Prestação de Serviços ao Público e Parcerias Público-Privadas: demarcando as fronteiras dos conceitos de serviço público, serviços de relevância pública e serviços de exploração econômica para as parcerias público-privadas. Revista Eletrônica de Direito Administrativo Econômico, Salvador, Instituto de Direito Público da Bahia, no 2, maio-jun-jul, 2005. Disponível na Internet: 〈http:www.direitodoestado.com.br〉. Acesso em: 18 de dezembro de 2013, p. 13).

22 “Em termos gerais, as PPP's propõem-se combinar os pontos fortes dos sectores público e privado, ...”. (AZEVEDO, Maria Eduarda. Parcerias Público-Privadas: instrumento de uma nova governança pública. 2008. Tese para obtenção do título de Doutora em Direito - Faculdade de Direito de Lisboa, p. 150.)

23 "Resta evidente, em consequência, que, nas parcerias públicas-privadas, a Lei Federal n. 11.079/04 rompe com a tradição, observada nas legislações que a precederam, de estabelecer, previamente, quais os riscos que competiriam a cada uma das partes, determinando, ao revés, que o contrato preveja tal repartição, de forma objetiva, no que se revela o reconhecimento de uma alocação contratual dos riscos do empreendimento". (NUNES, Thiago Mesquita. Da alocação de riscos enquanto fundamento subjacente ao equilíbrio econômicofinanceiro dos contratos administrativos. IN: Revista brasileira de direito administrativo e regulatório. São Paulo: Editora MP, V. 5, 2012, p. 234).
} 
concursos públicos para seleção de pessoal, as regras constitucionais sobre servidores públicos e sobre finanças públicas. A justificativa é a busca da eficiência que se alega ser maior no setor privado do que no setor público. ${ }^{24}$

\section{DA FORMATAÇÃO DAS PARCERIAS PÚBLICAS E PRIVADAS SEGUNDO AS DISPOSIÇÕES DA LEI No 11.079/04}

\section{1. Âmbito de aplicação da lei}

A Lei $n^{\circ} 11.079 / 04$ é um dispositivo redacional no qual se extrai normas gerais ${ }^{25}$ sobre contratação, possuindo regras específicas de licitação para o tipo de contrato em tela veiculado, bem como normas especificas destinadas ao âmbito federal.

Dessa forma, o conjunto normativo trazido pelo dispositivo legal supra, não é, em sua inteireza, norma a se aplicar a todos os entes da República Federativa do Brasil e a administração indireta, como prescrito no artigo prefacial da mesma:

Art. $1^{\circ}$ Esta Lei institui normas gerais para licitação e contratação de parceria público-privada no âmbito dos Poderes da União, dos Estados, do Distrito Federal e dos Municípios.

Parágrafo único. Esta Lei se aplica aos órgãos da Administração Pública direta, aos fundos especiais, às autarquias, às fundações públicas, às empresas públicas, às sociedades de economia mista e às demais entidades controladas direta ou indiretamente pela União, Estados, Distrito Federal e Municípios.

Tratando das normas gerais, essa lei não se limita ao âmbito da União, ao contrário, tem aplicabilidade na dimensão nacional, devendo ser obedecido por todos os entes da administração direta e indireta.

É fulcral trazer à baila a crítica, não sem razão, da professora Maria Sylvia Zanella Di Pietro, no que tange ao conteúdo do parágrafo único, supra. Ela chama a atenção ao fato de que a administração pública indireta é criada com uma finalidade específica, constituindo uma outorga de serviço público, ou seja, se por meio da outorga há a descentralização

\footnotetext{
${ }^{24}$ DI PIETRO, Maria Sylvia Zanella. Parcerias na administração pública. $9^{\circ}$ ed. São Paulo: Editora Atlas, 2012, p. 146.

${ }^{25}$ Constituição Federal. "Art. 22. Compete privativamente à União legislar sobre: ... XXVII - normas gerais de licitação e contratação, em todas as modalidades, para as administrações públicas diretas, autárquicas e fundacionais da União, Estados, Distrito Federal e Municípios, obedecido o disposto no art. 37, XXI, e para as empresas públicas e sociedades de economia mista, nos termos do art. 173, § $1^{\circ}$, III;”.
} 
administrativa, havendo a criação da entidade da administração indireta, esta não é, originariamente, a titular do serviço público. ${ }^{26}$

Como alguém, que não é titular do serviço público, a qual fora criado especificamente para prestá-lo, pode transferir para um terceiro privado realizá-lo? Não se pode transferir aquilo que não lhe pertence.

Explicita a professora Di Pietro, que a entidade da administração pública indireta só pode realizar um contrato de prestação de serviços, de execução de obra ou de fornecimento, com fulcro na Lei $\mathrm{n}^{\circ}$ 8.666/93, ou caso venha atuar como concessionária, realizar uma subconcessão, nos ditames do art. 26 de lei no $8.987 / 95 .{ }^{27}$

Doravante, ainda sobre essas normas gerais trazidas pela Lei $\mathrm{n}^{\circ} 11.079 / 04$, segundo as disposições constitucionais, tal competência legislativa não se restringe à esfera da União, podendo os Estados, Municípios e Distrito Federal, legislar normas complementares sobre a matéria de licitação e contratação de parceria público-privada no âmbito de suas respectivas administrações públicas. ${ }^{28}$

(...) somente as normas contempladas no texto da aludida Lei que possam ser qualificadas como gerais serão de observância compulsória para os entes federativos menores. Assim, há que se perquirir, caso a caso, quais dentre as normas da Lei $\mathrm{n}^{\circ} 11.079 / 2004$ descem de tal forma a minúcias ou detalhes, exaurindo o seu âmbito de normatividade, a ponto de perderem o status de norma geral. ${ }^{29}$

Constata-se normas que são restritas à esfera federal, não se aplicando aos demais entes da República Federativa do Brasil, como, por exemplo, a contida no art. 14 da lei das parcerias público-privadas, que determina a criação de um órgão gestor de parcerias públicoprivadas federais, o qual definiria os serviços prioritários, os procedimentos de celebração dos contratos, autorizaria abertura de licitação e aprovaria o edital, além de apreciar os relatórios de execução dos contratos.

Em suma, cria-se um órgão controlador e fiscalizador das parcerias público-privadas que ocorre em nível federal.

\footnotetext{
${ }^{26}$ Cf. DI PIETRO, Maria Sylvia Zanella. Direito Administrativo. 24º ed. São Paulo: Editora Atlas, 2011, p. 308.

${ }^{27}$ Cf. DI PIETRO, Maria Sylvia Zanella. Direito Administrativo. 24º ed. São Paulo: Editora Atlas, 2011, p. 308.

${ }^{2828}$ Destaca-se algumas leis estaduais que foram anteriores a Lei $\mathrm{n}^{\circ} 11.079 / 04$ : Lei $\mathrm{n}^{\mathrm{o}} 14.869 / 93$ do Estado de Minas Gerais; Lei n ${ }^{\circ}$ 11.688/04 do Estado de São Paulo, Lei n 12.234/05 do Estado do Rio Grande do Sul; Lei $n^{\circ}$ 14.910/04 do Estado de Goiás. Na esfera municipal houve a Lei n 6.261/04 do Município de Vitória.

${ }^{29}$ BINENBOJM, Gustavo. As Parcerias Público-Privadas (PPPs) e a Constituição. Revista Eletrônica de Direito Administrativo Econômico, Salvador, Instituto de Direito Público da Bahia, no 2, maio-jun-jul, 2005. Disponível na Internet: <http:www.direitodoestado.com.br〉. Acesso em: 18 de dezembro de 2013, p. 10.
} 
Assevera-se que, as normas estaduais ou municipais promulgadas anteriormente às normas gerais contidas na Lei $\mathrm{n}^{\circ} 11.079 / 04$, permaneceram válidas no que for compatível com a norma geral veiculada pela União. Naquilo que for contrário, as normas estaduais ou municipais terão sua eficácia suspensa.

Destaca-se que em matéria de contratos de parceiras públicas e privadas, além das normas extraídas da Lei n 11.079/04, far-se-á uso, subsidiariamente, das normas gerais sobre o regime de concessão e permissão da prestação de serviços públicos, contidos na Lei $\mathrm{n}^{\circ}$ 8.987/95, bem como das normas gerais das licitações e contratos da Administração Pública, da Lei $n^{\circ} 8.666 / 93 .{ }^{30}$

No que tange ao uso subsidiário da Lei $n^{\circ} 8.987 / 95$, a redação prefacial da Lei $n^{\circ}$ 11.079/04 é expressa sobre a matéria:

Art. $3^{\circ} \ldots$

$\S 1^{\circ}$ As concessões patrocinadas regem-se por esta Lei, aplicando-se-lhes subsidiariamente o disposto na Lei $\mathrm{n}^{\circ}$ 8.987, de 13 de fevereiro de 1995, e nas leis que lhe são correlatas. (Grifos nossos)

Em relação à Lei $n^{\circ}$ 8.666/93, esta é referida em diversas passagens da lei da parceria público-privada, ${ }^{31}$ além do mais o seu uso dar-se por uma questão dialógica normativa das regras e princípios que compõe o sistema jurídico. ${ }^{32}$

Só a título de exemplo, por mais que a lei das parceria público-privada tragam o indicativo de certas cláusulas contratuais fundamentais a mesma, isso não descarta o conjunto de cláusulas que compõe o contrato administrativo previsto na Lei $\mathrm{n}^{\circ} 8.666 / 93$, salvo é claro, naquilo que forem incompatíveis. Nisso dar-se o diálogo intrassistêmicos.

\subsection{Por que usar a parceira pública e privada?}

\footnotetext{
30 “A Lei n 11.079/2004 é apenas mais uma lei geral (ou lei-quadro) sobre contratação pública (aludida no art. 22, XXVII, CF), que vem se somar às Leis $n^{\circ} 8.666 / 93$ e 8.987/95 (além das demais leis setoriais) ao fito de proporcionar à Administração Pública os meios jurídicos para desenvolver, da forma mais eficiente possível, a prestação de serviços públicos (...)”. (BINENBOJM, Gustavo. As Parcerias Público-Privadas (PPPs) e a Constituição. Revista Eletrônica de Direito Administrativo Econômico, Salvador, Instituto de Direito Público da Bahia, $n^{\circ}$ 2, maio-jun-jul, 2005. Disponível na Internet: 〈http:www.direitodoestado.com.br〉. Acesso em: 18 de dezembro de 2013, p. 07).

${ }^{31}$ Lei $n^{\circ} 11.079 / 04$. "Art. $5^{\circ}$ VIII - a prestação, pelo parceiro privado, de garantias de execução suficientes e compatíveis com os ônus e riscos envolvidos, observados os limites dos $\S \S 3^{\circ}$ e $5^{\circ}$ do art. 56 da Lei $n^{\circ} 8.666$, de 21 de junho de 1993, e ...”. "Art. 11... I - exigência de garantia de proposta do licitante, observado o limite do inciso III do art. 31 da Lei no 8.666, de 21 de junho de 1993;”.

32 "Incidem sobre tais contratos o princípio da desigualdade das partes e as cláusulas exorbitantes peculiares aos contratos administrativos previstos nas Leis $n^{\circ} 8.666 / 1993$ e 8.987/1995, entre elas a alteração e a rescisão unilateral do contrato e a aplicabilidade de sanções administrativas". CARVALHO FILHO, José dos Santos. Manual de Direito Administrativo. 25 ed. São Paulo: Editora Atlas, 2012, p. 425.
} 
A administração pública, como visto supra, é destinatária de diversos dispositivos legais que tratam sobre as formas que a mesma irá contratar com a entidade privada.

Far-se-á uso da modelação contratual trazida pela Lei ${ }^{\circ} 11.079 / 04$, quando do caso concreto as formas contratuais da Lei ${ }^{\circ} 8.666 / 93$ e da Lei $n^{\circ} 8.987 / 95$ não forem vantajosas economicamente e socialmente.

Em situações nas quais deva prevalecer com exclusividade o regime público, utiliza-se a modelagem da Lei $n^{\circ}$ 8.666/93. Em caso de empreendimento autossustentável, a entidade privada se responsabiliza exclusivamente pelos riscos, fazendo uso da modelagem dos contratos de concessão da Lei $n^{\circ} 8.987 / 95 .^{33}$

Já nos empreendimentos de valores extremamente vultosos, em que há uma alta complexidade em seu conjunto, cujos riscos (internos e externos) são extremamente elevados, sem falar daqueles que são desconhecidos em face de uma assimetria de informação, de um ambiente jurídico e econômico instável, ${ }^{34}$ a entidade privada não possui um natural interesse.

Soma-se a essa realidade a incapacidade de alocamento de recursos públicos, de forma imediata e a longo prazo. De tal modo, vem-se por socorrer dos contratos da Lei $\mathrm{n}^{\circ}$ $11.079 / 04 .^{35}$

Esse contexto justificador do uso da concessão de parceria pública e privada deve ser retratado nos fundamentos da administração pública. Não é pertinente/razoável o uso indiscriminado dessa modelagem contratual sem um plano de fundo explicitado que o legitime. ${ }^{36}$

Por isso, as duas modalidades de contratação de parcerias público privadas (conhecidas no continente europeu também pela sigla PPP, Public-PrivatePartnerships) apresentam caráter subsidiário em relação às denominadas concessões comuns. Somente parece legítima a adoção das novas modalidades quando inviável, por manifesto desinteresse dos capitais privados e insuficientes recursos de investimento do poder público, a adoção

\footnotetext{
${ }^{33}$ Cf. NÓBREGA, Marcos. Direito da Infraestrutura. São Paulo, Quartier Latin, 2011, p. 61.

${ }^{34}$ Cf. NÓBREGA, Marcos. Contratos incompletos e infraestrutura: contratos administrativos, concessões de serviço público e PPPs. IN: Revista brasileira de direito administrativo e regulatório. São Paulo: Editora MP, V. 1, 2010, p. 126.

${ }^{35}$ Nos casos de contratos de parceiras públicas e privadas vem à tona o "valeu of Money" (VOM) do projeto, ou seja, mais do que uma aferição de custos monetários, preocupa-se com o benefício total que o empreendimento pode gerar. "Value of Money procura captar o benefício total do projeto executado, considerando seu custo durante toda a sua vida útil a qualidade do bem ou serviço prestado e as externalidades geradas, tais como crescimento econômico, impacto ambiental, mobilização de recursos, impacto social e governança. (...)”. (NÓBREGA, Marcos. Direito da Infraestrutura. São Paulo, Quartier Latin, 2011, p. 61).

36 “(...) reforça o nosso entendimento de que os contratos de PPP somente seriam viáveis e justificáveis se fossem mais vantajosos do que a prestação direta do serviço pelo Estado". (NÓBREGA, Marcos. Direito da Infraestrutura. São Paulo, Quartier Latin, 2011, p. 76).
} 
da modalidade comum de concessões de serviço, de obra ou de uso de bem público, bem como a contratação direta em regime de empreitada. ${ }^{37}$

No escólio de Binenbojm:

(...) Dado o caráter excepcional da PPP, em tal estudo deverá ser demonstrado que a opção por tal forma de contratação é aquela que, comparativamente às demais existentes, é a que melhor (ou mesmo a única) capaz de alavancar os investimentos necessários ao desenvolvimento de determinado projeto, propiciando, ainda, a mais otimizada maneira de dispêndio dos recursos públicos envolvidos vis-à-vis do grau de benefício econômico e social trazido para a população. Assim concebido, o contrato de PPP me parece ser uma solução legislativa que permite o alcance, conforme as circunstâncias do caso concreto, de um maior grau de concretização do princípio da eficiência administrativa (CF, art. 37, caput). ${ }^{38}$

As razões pela opção desse tipo de concessão, não só é uma premissa lógica, como é um dever legal que fora positivado pela própria Lei $\mathrm{n}^{\mathrm{o}}$ 11.079/04:

Art. 10. A contratação de parceria público-privada será precedida de licitação na modalidade de concorrência, estando a abertura do processo licitatório condicionada a:

I - autorização da autoridade competente, fundamentada em estudo técnico que demonstre:

a) a conveniência e a oportunidade da contratação, mediante identificação das razões que justifiquem a opção pela forma de parceria público-privada; (Grifos nossos)

\subsection{Modalidades de parceiras públicas e privadas}

Em um trabalho realizado pela Comissão Econômica das Nações Unidas para a Europa sobre as parceiras públicas e privadas, ${ }^{39}$ são apresentadas diversas formas de configuração de uma parceira pública e privada, em que as responsabilidades e os riscos dos parceiros são configurados diferentemente, da seguinte forma: Buy-Build-Operate (BBO); Build-Own-Operate (BOO); Build-Own-Operate-Transfer (BOOT); Build-Operate-Transfer

\footnotetext{
${ }^{37}$ MODESTO, Paulo. Reforma do Estado, Formas de Prestação de Serviços ao Público e Parcerias PúblicoPrivadas: demarcando as fronteiras dos conceitos de serviço público, serviços de relevância pública e serviços de exploração econômica para as parcerias público-privadas. Revista Eletrônica de Direito Administrativo Econômico, Salvador, Instituto de Direito Público da Bahia, no 2, maio-jun-jul, 2005. Disponível na Internet: <http:www.direitodoestado.com.br〉. Acesso em: 18 de dezembro de 2013, p. 34.

${ }^{38}$ BINENBOJM, Gustavo. As Parcerias Público-Privadas (PPPs) e a Constituição. Revista Eletrônica de Direito Administrativo Econômico, Salvador, Instituto de Direito Público da Bahia, no 2, maio-jun-jul, 2005. Disponível na Internet: <http:www.direitodoestado.com.br〉. Acesso em: 18 de dezembro de 2013, p. 07.

${ }^{39}$ United Nations Economic Comission for Europe. Guidebook on promoting good governance in publicprivate partnerships. Geneve, 2008. 20 Disponível em: <http://www.unece.org/fileadmin/DAM/ceci/publications/ppp.pdf>. Acesso em: 20 de dezembro de 2013, ps. 02-03.
} 
(BOT); Build-Lease-Operate-Transfer (BLOT); Design-Build-Finance-Operate (DBFO); Finance Only; Operation \& Maintenance Contract (O \& M); Design-Build (DB); e Operation License.

O professor Marcos Nobrega identifica o modelo Build-Operate-Transfer (BOT) como aquele que mais se ajusta a formatação contratual brasileira, ${ }^{4041}$ nesse formato a entidade privada projeta, financia e constrói uma nova infraestrutura, tendo um contrato de concessão de longa duração, transferindo, posteriormente, para o setor público.

2.3.1. A formatação da modelagem de parceiras públicas e privadas segundo as disposições da Lei $\mathrm{n}^{\circ} 11.079 / 04$

As parceiras públicas e privadas, no Brasil, desenvolvem-se de duas maneiras: um contrato de concessão na sua forma patrocinada ${ }^{42}$ ou um contrato de concessão da sua forma administrativa.

\subsubsection{Da concessão patrocinada (subsidiada, subvencionada ou receita mínima assegurada)}

Neste modelo, a concessão de serviço público ou de obra pública tem como elemento distintivo o fato de o parceiro privado além de receber o valor referente às tarifas cobradas dos usuários dos serviços, soma-se a isso, uma contraprestação pecuniária feita pelo parceiro público. $^{43}$

A lógica por traz dessa modalidade está em atividades econômicas não autossustentáveis. ${ }^{44}$

\footnotetext{
${ }^{40}$ NÓBREGA, Marcos. Direito da Infraestrutura. São Paulo, Quartier Latin, 2011, p. 59.

41 “(...) nas formatações do tipo BOT, há riscos que são mais contundentes em específicas fases do projeto, conquanto as estratégias de minimização de risco dever ser consideradas para cada fase per si. Dessa forma, três grandes etapas podem ser consideradas: a) a fase de elaboração do projeto e da construção; b) a fase de início de funcionamento (start-up); e c) a fase de operação. Os riscos em geral são bastante altos, considerando que o desenvolvimento do projeto é complexo, demandando bastante tempo e recursos. Assim, o nível de negociações entre as partes é demorado, determinando elevados custos de transação e de oportunidade". (NÓBREGA, Marcos. Direito da Infraestrutura. São Paulo, Quartier Latin, 2011, p. 133).

${ }^{42}$ A ideia de concessão patrocinada estava contido no projeto de lei que originou a lei $\mathrm{n}^{\mathrm{o}} 8.987 / 95$, todavia, sofrera veto presidencial. Segue as razões do veto: "Garantias como essa do estabelecimento de receita bruta mínima, além de incentivarem ineficiência operacional do concessionário, representam, na realidade, um risco potencial de dispêndio com subsidio pelo Poder Público. O caso mais recente foi o mecanismo instituído pela Lei $\mathrm{n}^{\circ}$ 5.655/71, que criou a Conta de Resultados a Compensar (CRC), extinta, em 18.3.93, com a regulamentação da Lei ${ }^{\circ}$ 8.631/93, gerando dispêndios líquidos para a União da ordem de US\$ 19,8 bilhões". BRASIL. Mensagem n ${ }^{\circ}$ 181, de 13 de fevereiro de 1995. Diário Oficial da União. Brasília, DF, 14 de fevereiro de 1995. Disponível em: <http://www.planalto.gov.br/ccivil_03/leis/Mensagem_Veto/anterior_98/vep-18195.htm>. Acesso em: 18 de dezembro de 2013.

${ }^{43}$ Art. $2^{\circ}, \S 1^{\circ}$ da Lei no $11.079 / 04$.

${ }^{44}$ BINENBOJM, Gustavo. As Parcerias Público-Privadas (PPPs) e a Constituição. Revista Eletrônica de Direito Administrativo Econômico, Salvador, Instituto de Direito Público da Bahia, nº 2, maio-jun-jul, 2005. Disponível na Internet: <http:www.direitodoestado.com.br>. Acesso em: 18 de dezembro de 2013, p. 05.
} 
O objeto das concessões patrocinadas é, por excelência, os serviços públicos econômicos, atividades econômicas lato sensu titularizadas com exclusividade pelo Estado, suscetíveis de exploração pela iniciativa privada apenas mediante delegação, já que passíveis de exploração mediante pagamento de tarifas pelos usuários, ainda que o valor pago não seja suficiente para financiar todos os investimentos do concessionário. ${ }^{45}$

\subsubsection{Da concessão administrativa}

Já no caso da concessão administrativa, a entidade pública é a usuária, direta ou indiretamente, do contrato de prestação de serviços, ainda que envolva execução de obra ou fornecimento e instalação de bens. ${ }^{46}$

Nesse contexto se estrai dois tipos de concessão administrativa: concessão administrativa de serviço público (nessa a prestação do serviço é feita diretamente ao usuário, sem o Estado usuário indireto); e concessão administrativa de serviços ao Estado (o serviço é oferecido ao próprio Estado, diretamente). ${ }^{47}$

(...) "concessões administrativas" são contratos em que a cobrança de tarifas é inviável econômica ou socialmente, de acordo com decisão política a ser discricionária e fundamentadamente tomada pelo Estado, ou até mesmo juridicamente vedada, como a cobrança pela saúde ou educação públicas (artigos 196 e 206, IV , CF), ou ainda porque o único usuário do serviço a ser prestado é o próprio Estado. $(. . .)^{48}$

Destaca-se que, a lógica fundante da concessão administrativa de serviço público está no fato de por razões técnicas, econômicas e/ou políticas, a cobrança de tarifas aos usuários diretos do serviço é inviável, sendo o mesmo custeado pelo poder público. Assim, na

\footnotetext{
${ }^{45}$ ARAGÃO, Alexandre Santos de. As Parcerias Público-Privadas - PPP's no Direito Positivo Brasileiro. Revista Eletrônica de Direito Administrativo Econômico, Salvador, Instituto de Direito Público da Bahia, ${ }^{\circ}$ 2, maio-jun-jul, 2005. Disponível na Internet: 〈http:www.direitodoestado.com.br〉. Acesso em: 18 de dezembro de 2013, p. 07.

${ }^{46}$ Art. $2^{\circ}, \S 2^{\circ}$ da Lei no $11.079 / 04$.

${ }^{47}$ BINENBOJM, Gustavo. As Parcerias Público-Privadas (PPPs) e a Constituição. Revista Eletrônica de Direito Administrativo Econômico, Salvador, Instituto de Direito Público da Bahia, $\mathrm{n}^{\circ}$ 2, maio-jun-jul, 2005. Disponível na Internet: 〈http:www.direitodoestado.com.br〉. Acesso em: 18 de dezembro de 2013, p. 04.

${ }^{48}$ ARAGÃO, Alexandre Santos de. As Parcerias Público-Privadas - PPP's no Direito Positivo Brasileiro.

Revista Eletrônica de Direito Administrativo Econômico, Salvador, Instituto de Direito Público da Bahia, ${ }^{\circ}$ 2, maio-jun-jul, 2005. Disponível na Internet: 〈http:www.direitodoestado.com.br〉. Acesso em: 18 de dezembro de 2013, p. 12.
} 
concessão administrativa de serviços ao Estado tem-se o desiderato do aumento da performance no gerenciamento de obras e serviços público, bem como nas despesas estatais. ${ }^{49}$

Afere-se que nessa modalidade de concessão a entidade privada não será remunerada por meio de sistema tarifário, bem como tem uma possibilidade de atuação muito maior do que a concessão patrocinada, a qual se restringe aos serviços públicos econômicos. ${ }^{50}$

Tem-se como característica distintiva, marcante, apesar de não ser a única, do contrato de concessão de parceria pública e privada a contraprestação financeira por parte da entidade pública em relação a entidade privada.

(...) A distinção fundamental, portanto, entre a nova concessão administrativa e a concessão comum (regida pela Lei $n^{\circ}$ 8.987/95) está na forma de remuneração do concessionário: na primeira, o Poder Público comparece com pagamentos de natureza pecuniária, complementares à tarifa; na segunda, além da cobrança da tarifa, pode o concessionário ser remunerado por receitas alternativas (Lei ${ }^{\circ}$ 8.987/95), desde que estas não envolvam pagamentos de natureza pecuniária feitos pela Administração Pública. ${ }^{51}$

A ausência de tal contraprestação financeira por parte da parceira pública desnatura essa modalidade de contrato administrativo, configurando mero contrato de concessão comum regido pela Lei $n^{\circ} 8.987 / 95,{ }^{52}$ como determina o art. $2^{\circ}, \S 3^{\circ}$ da lei instituidora da PPPs:

$\S 3^{\circ}$ Não constitui parceria público-privada a concessão comum, assim entendida a concessão de serviços públicos ou de obras públicas de que trata a Lei $\mathrm{n}^{\circ}$ 8.987, de 13 de fevereiro de 1995, quando não envolver contraprestação pecuniária do parceiro público ao parceiro privado.

Em face do já explicitado, fica claro que o contrato de parceria pública e privada não é nada estranho ao ordenamento jurídico brasileiro, mas sim uma evolução do modelo contratual da concessão administrativa. ${ }^{53}$

\footnotetext{
${ }^{49}$ BINENBOJM, Gustavo. As Parcerias Público-Privadas (PPPs) e a Constituição. Revista Eletrônica de Direito Administrativo Econômico, Salvador, Instituto de Direito Público da Bahia, no 2, maio-jun-jul, 2005. Disponível na Internet: 〈http:www.direitodoestado.com.br〉. Acesso em: 18 de dezembro de 2013, p. 05.

${ }^{50}$ ARAGÃO, Alexandre Santos de. As Parcerias Público-Privadas - PPP's no Direito Positivo Brasileiro. Revista Eletrônica de Direito Administrativo Econômico, Salvador, Instituto de Direito Público da Bahia, ${ }^{\circ}$ 2, maio-jun-jul, 2005. Disponível na Internet: 〈http:www.direitodoestado.com.br〉. Acesso em: 18 de dezembro de 2013, p. 13.

${ }^{51}$ BINENBOJM, Gustavo. As Parcerias Público-Privadas (PPPs) e a Constituição. Revista Eletrônica de Direito Administrativo Econômico, Salvador, Instituto de Direito Público da Bahia, no 2, maio-jun-jul, 2005. Disponível na Internet: 〈http:www.direitodoestado.com.br〉. Acesso em: 18 de dezembro de 2013, p. 02.

52 "A concessão comum de serviço público é um contrato plurilateral de natureza organizacional e associativa, por meio do qual a prestação de um serviço público é temporariamente delegada pelo Estado a um sujeito privado que assume seu desempenho mente em face dos usuários, mas sob controle estatal e da sociedade civil, mediante remuneração extraída do empreendimento". (JUSTEN FILHO, Marçal. Curso de Direito Administrativo. $9^{\circ}$ ed. São Paulo: Revista dos Tribunais, 2013, p. 761).
} 


\subsubsection{Do aspecto constitucional}

Na época da publicação da lei instituidora das parcerias públicas e privadas, a mera possibilidade desse tipo de contratação, na qual o setor privado é subsidiado, total ou parcialmente, pelo setor público, fora motivo de uma filtragem constitucional, em que se argumentou pela sua inadequação à normativa da Constituição Federal, visto que no art. $175,{ }^{54}$ sobre o regime de concessão e permissão, determinou-se que a lei especificaria a política tarifária.

De tal sorte, fora feita uma interpretação restritiva no que se refere às delegações públicas, uma vez que o setor privado só poderia ser remunerado pelas tarifas pagas pelos usuários do serviço público, vedando a chamada "tarifa-zero" (remuneração exclusiva feita pelo poder público a ente privado).

Todavia, pode-se dar um outro viés. Interpretar, de forma que, a política tarifária seria uma das formas de remuneração, e não a única.

Não é possível admitir que o Constituinte tenha engessado de tal maneira o Legislador, a ponto de colocá-lo sempre atado a uma definição doutrinária tradicional de concessão, indiferente a todas as enormes mudanças sociais, econômicas e políticas verificadas após 05 de outubro de 1988. Ademais, "política tarifária" pode perfeitamente ser entendida como a política segundo a qual a tarifa deve cobrir apenas parte do custo do serviço público, sendo o restante arcado pelo Estado. ${ }^{55}$

Pensar diferente causaria o alijamento da administração pública, de uma importante técnica de renovação e prestação do serviço público, tornando-se um obste à busca da concretização de inúmeros direitos basilares, como a saúde, o transporte, o desenvolvimento, dentre outros.

\footnotetext{
${ }^{53}$ Cf. SILVA, Roberta Cruz da. Entre o endeusamento e a descrença: a perigosa visão dicotômica sobre o contrato de parceria pública-privada na seara administrativa brasileira. IN: Revista brasileira de direito administrativo e regulatório. São Paulo: Editora MP, V. 4, 2011, p. 208.

${ }^{54}$ Constituição Federal. Art. 175. Incumbe ao Poder Público, na forma da lei, diretamente ou sob regime de concessão ou permissão, sempre através de licitação, a prestação de serviços públicos.

Parágrafo único. A lei disporá sobre: I - o regime das empresas concessionárias e permissionárias de serviços públicos, o caráter especial de seu contrato e de sua prorrogação, bem como as condições de caducidade, fiscalização e rescisão da concessão ou permissão; II - os direitos dos usuários; III - política tarifária; IV - a obrigação de manter serviço adequado.

${ }^{55}$ ARAGÃO, Alexandre Santos de. As Parcerias Público-Privadas - PPP's no Direito Positivo Brasileiro. Revista Eletrônica de Direito Administrativo Econômico, Salvador, Instituto de Direito Público da Bahia, ${ }^{\circ}$ 2, maio-jun-jul, 2005. Disponível na Internet: 〈http:www.direitodoestado.com.br〉. Acesso em: 18 de dezembro de 2013, p. 09.
} 
O formato do contrato de concessão das parcerias públicas e privadas não vem por obstaculizar os valores constitucionais, ${ }^{56}$ mas sim, como mais uma opção de realização desses ditames. Ademais, em nenhum momento o texto constitucional especificou a modelagem contratual das concessões e permissões públicas, deixando tal encargo ao legislador, o qual, nos limites constitucionais, pode fazer uso das mais variadas. ${ }^{57}$

\subsection{Requisitos mínimos para constituição do contrato no modelo de PPPs}

No art. $2^{\circ}, \S 4^{\circ}$, da Lei $n^{\circ} 11.079 / 04$, é elegida as chamadas "cláusulas de barreira"58 para a constituição de um contrato administrativo de concessão, na modalidade parceria pública e privada.

Doravante, da modelagem contratual, não pode ser utilizado quando do valor transacionado esteja abaixo a vinte milhões de reais, com duração contratual inferior a cinco anos ou superior a 35 anos, tendo por objeto exclusivo o fornecimento de mão-de-obra, o fornecimento e instalação de equipamentos ou a execução de obra pública.

De tal sorte, evidencia-se que o objeto da PPPs seria a prestação de um serviço público, esta atividade de utilizada de ou comodidade material fluível pelos administrados, que pode englobar o fornecimento de mão-de-obra, o fornecimento e instalação de equipamentos ou a execução de obra pública. ${ }^{59}$

O regramento que dispõe sobre o valor mínimo de vinte milhões de reais não deve ser interpretado como uma norma geral, sob o risco de inviabilizar o uso dessa modelagem contratual aos outros entes da República Federativa do Brasil que não fosse a União. ${ }^{60}$

\footnotetext{
${ }^{56}$ Cf. CARVAlHO FILHO, José dos Santos. Manual de Direito Administrativo. $25^{\circ}$ ed. São Paulo: Editora Atlas, 2012, p. 425.

57 "Não há, portanto, um conceito universal de "concessão de serviço público" pelo qual o Constituinte teria vinculado o Legislador, razão pela qual afigura-se plenamente constitucional, face ao art. 175 da CF, a previsão legal de concessões financeiramente apoiadas pelo Estado, seja pelo pagamento direto de uma quantia a ser determinada, seja pela garantia de receita mínima ou de uma dada quantidade de usuários". (ARAGÃO, Alexandre Santos de. As Parcerias Público-Privadas - PPP's no Direito Positivo Brasileiro. Revista Eletrônica de Direito Administrativo Econômico, Salvador, Instituto de Direito Público da Bahia, $\mathrm{n}^{\circ}$ 2, maio-jun-jul, 2005. Disponível na Internet: 〈http:www.direitodoestado.com.br〉. Acesso em: 18 de dezembro de 2013, p. 12).

${ }^{58}$ Cf. NÓBREGA, Marcos. Direito da Infraestrutura. São Paulo, Quartier Latin, 2011, p. 90.

${ }^{59}$ Cf. MELlO, Celso Antônio Bandeira de. Curso de direito administrativo. 27 ed. São Paulo: Malheiros Editora, 2010, p. 776.

60 “(...) O valor de 20 milhões de reais praticamente inviabiliza as PPPs em pequenas municipalidades (...)”. (NÓBREGA, Marcos. Direito da Infraestrutura. São Paulo, Quartier Latin, 2011, p. 90). Cf. BINENBOJM, Gustavo. As Parcerias Público-Privadas (PPPs) e a Constituição. Revista Eletrônica de Direito Administrativo Econômico, Salvador, Instituto de Direito Público da Bahia, ${ }^{\circ}$ 2, maio-jun-jul, 2005. Disponível na Internet: <http:www.direitodoestado.com.br>. Acesso em: 18 de dezembro de 2013, ps. 09-10). Em defesa do texto legal, segue as palavras do professor: "Já não são poucos os que vem questionando a aplicabilidade dessas normas aos Estados e Municípios por estabelecerem detalhes de prazo e de valor que não se coadunariam com a natureza de normas gerais. Argúem, sobretudo, que o valor de R \$ 20 milhões é elevado para muitos municípios. Não nos parece que seja assim, pois, como demonstrado acima, as normas se relacionam com o objetivo geral de as
} 


\subsection{Diretrizes para a contração de parceria público-privada}

O contrato de concessão de parceria público-privada possui as seguintes diretrizes regentes: a) eficiência no cumprimento das missões de Estado e no emprego dos recursos da sociedade; b) respeito aos interesses e direitos dos destinatários dos serviços e dos entes privados incumbidos da sua execução; c) indelegabilidade das funções de regulação, jurisdicional, do exercício do poder de polícia e de outras atividades exclusivas do Estado; d) responsabilidade fiscal na celebração e execução das parcerias; e) transparência dos procedimentos e das decisões; f) repartição objetiva de riscos entre as partes; e g) sustentabilidade financeira e vantagens socioeconômicas dos projetos de parceria. ${ }^{61}$

No que tange a "indelegabilidade das funções de regulação, jurisdicional, do exercício do poder de polícia e de outras atividades exclusivas do Estado", o professor Celso Antônio Bandeira de Mello tece críticas a esse enunciado redacional tendo em vista sua desnecessidade, pois por óbvio, tais atividades estatais não configuram serviço público, no nosso ordenamento jurídico, ou está fora da esfera das PPPs. ${ }^{62}$

\subsection{Das garantias das obrigações firmadas pela Administração Pública}

Como já explicitado, contrato de parcerias público-privadas busca uma modelagem contratual que atenda a empreendimentos vultosos, de riscos muito elevados. As garantias contratuais previstas na Lei $n^{\circ} 8.987 / 95$ e na Lei $n^{\circ} 8.666 / 93$ não estão a contento a essas especificidades.

Neste diapasão, a Lei $\mathrm{n}^{\circ}$ 11.079/04 comtempla um novo feixe de garantias de forma a reduzir os riscos, tornando o empreendimento atrativo ao setor privado.

Assim dispõe o art. $8^{\circ}$ da lei em comento:

Art. 8o As obrigações pecuniárias contraídas pela Administração Pública em contrato de parceria público-privada poderão ser garantidas mediante:

parcerias público-privadas serem utilizadas seletivamente apenas para grandes projetos de infra-estrutura, além de se ter que considerar os elevados riscos fiscais que acarretam, e um número menor de parcerias públicoprivadas é mais fácil de se controlar. O fato desse legítimo objetivo geral muitas vezes não ser aplicável a pequenos municípios não faz com que a norma deixe de ser geral, já que combina o princípio da economicidade com o princípio da eficiência, centrando os escassos recursos públicos disponíveis em projetos que realmente sejam capazes de dar sustentabilidade ao desenvolvimento. O que a Lei pretende é que as parcerias públicoprivadas não sejam utilizadas para projetos que não tenham grande magnitude, não evitar que pequenos municípios se utilizem delas (...)”. (ARAGÃO, Alexandre Santos de. As Parcerias Público-Privadas - PPP's no Direito Positivo Brasileiro. Revista Eletrônica de Direito Administrativo Econômico, Salvador, Instituto de Direito Público da Bahia, no 2, maio-jun-jul, 2005. Disponível na Internet: 〈http:www.direitodoestado.com.br〉. Acesso em: 18 de dezembro de 2013, p. 18).

${ }^{61}$ Art. $4^{\circ}$ da Lei no $11.079 / 04$.

${ }^{62}$ Cf. MELlO, Celso Antônio Bandeira de. Curso de direito administrativo. 27 ed. São Paulo: Malheiros Editora, 2010, p. 774. 
I - vinculação de receitas, observado o disposto no inciso IV do art. 167 da Constituição Federal;

II - instituição ou utilização de fundos especiais previstos em lei;

III - contratação de seguro-garantia com as companhias seguradoras que não sejam controladas pelo Poder Público;

IV - garantia prestada por organismos internacionais ou instituições financeiras que não sejam controladas pelo Poder Público;

$\mathrm{V}$ - garantias prestadas por fundo garantidor ou empresa estatal criada para essa finalidade;

VI - outros mecanismos admitidos em lei.

Esse artigo, prefacialmente, já dá ensejo a uma discursão sobre sua constitucionalidade, tendo em vista aparente afronta ao art. 163, IV da Constituição Federal, ${ }^{63}$ o qual dispõe que só por lei complementar se disporá sobre concessão de garantias pelas entidades públicas.

Ter-se-ia, uma inconstitucionalidade formal, em que uma lei ordinária, a Lei $\mathrm{n}^{\circ}$ 11.079/04, veicularia matéria de lei complementar.

Os defensores da constitucionalidade do artigo supra trazem à baila os seguintes argumentos: “(...) sustenta ter a Lei $\mathrm{n}^{\circ}$ 11.079/2004 apenas regulamentado a Lei Complementar $\mathrm{n}^{\circ}$ 101/200 (Lei de Responsabilidade Fiscal), com o que estaria satisfeita a exigência constitucional(...)"; “(...) o art. $8^{\circ}$ não trata da concessão de garantias por entidades públicas (referidas no caput do art. 163 da Constituição), mas sim por uma entidade privada, que é o Fundo Garantidor das Parcerias Público- Privadas (FGP)" ${ }^{64}$

2.6.1. A questão da constitucionalidade sobre o fundo garantidor de Parcerias PúblicoPrivadas (FGP)

Como acima prescrito, no texto legal, uma das hipóteses de garantia das obrigações pecuniárias do poder público perante o setor privado seria as garantias prestadas por fundo garantidor.

Este fundo garantidor de Parcerias Público-Privadas teria natureza privada, sendo constituído pela União, seus fundos especiais, suas autarquias, suas fundações públicas e suas

\footnotetext{
${ }^{63}$ Constituição Federal. Art. 163. Lei complementar disporá sobre: I - finanças públicas; II - dívida pública externa e interna, incluída a das autarquias, fundações e demais entidades controladas pelo Poder Público; III concessão de garantias pelas entidades públicas; IV - emissão e resgate de títulos da dívida pública; V fiscalização financeira da administração pública direta e indireta; VI - operações de câmbio realizadas por órgãos e entidades da União, dos Estados, do Distrito Federal e dos Municípios; VII - compatibilização das funções das instituições oficiais de crédito da União, resguardadas as características e condições operacionais plenas das voltadas ao desenvolvimento regional.

${ }^{64}$ BINENBOJM, Gustavo. As Parcerias Público-Privadas (PPPs) e a Constituição. Revista Eletrônica de Direito Administrativo Econômico, Salvador, Instituto de Direito Público da Bahia, no 2, maio-jun-jul, 2005. Disponível na Internet: 〈http:www.direitodoestado.com.br〉. Acesso em: 18 de dezembro de 2013, p. 12.
} 
empresas estatais dependentes autorizadas a participar, os quais teriam um limite de seis bilhões de reais, o qual garantiria as obrigações pecuniárias dos parceiros públicos federais, distritais, estaduais e municipais. ${ }^{65}$

Essa modalidade de garantia é extremamente inovadora e atende os reclames dos parceiros privados, vindo a diminuir os riscos e a desconfiança que as entidades privadas tem em favor do poder público.

É sabido que, em uma operação contratual normal, com a administração pública, esta desagua em uma demanda judicial, a qual é naturalmente demorada em face das prerrogativas da fazenda em juízo. ${ }^{66}$

Não bastando, quando do trânsito em julgado da sentença desfavorável à Fazenda, o contratado privado tem que submeter o seu crédito ao regime cronológico de pagamento dos precatórios, o qual é de conhecimento notório, que a depender da entidade da República Federativa do Brasil devedora, pode ultrapassar década. ${ }^{67}$

Em face dessa realidade, desse risco de "calote" por parte do poder público, a Lei $\mathrm{n}^{\circ}$ 11.079/04 autoriza a criação de um fundo, a partir de receitas e bens públicos (estes desafetados), o qual garantiria as obrigações pecuniárias do Poder Público assumido perante a parceira privada.

Dessa forma, tem-se patrimônio público convertido em privado, para garantir os investimentos do parceiro privado, desembaraçando-o do suplício do sistema de execução judicial precatorial, sem falar da demora não razoável dos processos onde a fazenda pública é parte.

Não há como negar, em termos operacionais, que tal instituto de garantia é admirável ao renovar a confiança entre os parceiros, ${ }^{6869}$ permitindo que tal modelação de contrato seja

\footnotetext{
${ }^{65}$ Art. 16 da Lei ${ }^{\circ} 11.079 / 04$.

66 "No plano substancial, estas prerrogativas são materializadas pelos princípios da legalidade e da continuidade do serviço público, além da discutível supremacia do interesse público. No âmbito processual, podem ser citados: a) prazos dilatados, em quádruplo para contestar e em dobro para recorrer; b) o duplo grau de jurisdição obrigatória, com as ressalvas da regra do art. 12 da MP 2.180-35/2001; c) a previsão de um processo especial de cobrança de seus créditos, pela via da execução fiscal; d) a dispensa de pagamento prévio de custas de ajuizamento e de interposição de recursos; e) restrições à concessão de liminares e antecipações de tutela contra seus aros; f) restrição à execução provisória; g) intimação pessoal, mediante carga ou remessa dos autos, h) dispensa de depósito para ajuizamento de ação rescisória; e i) prescrição quinquenal de seus débitos". (OLIVEIRA, Luís Fernando Lima de. O juízo de Salomão: eficiência, validade e limites do uso da arbitragem nas concessões públicas brasileiras. IN: Revista brasileira de direito administrativo e regulatório. São Paulo: Editora MP, V. 4, 2011, p. 142.)

67 "O resultado prático desse sistema, no âmbito de Estados e Municípios, tem sido desastroso. Os montantes devidos pela Fazenda Pública, embora incluídos no orçamento, acabam não sendo pagos. O resultado é a ausência de efetividade das decisões judiciais condenatórias da Fazenda Pública". (Cf. JUSTEN FILHO, Marçal. Curso de Direito Administrativo. $9^{\circ}$ ed. São Paulo: Revista dos Tribunais, 2013, p. 833).

68 "A questão surpreendente deriva da circunstância de que essa inovação foi necessária para afastar um regime de proteção e benefício em favor da Fazenda Pública. $\mathrm{O}$ aspecto chocante deriva da ausência de credibilidade do
} 
interessante ao parceiro privado, pois há uma diminuição, sensível, do risco de inadimplemento por parte do poder público, pois não terá que fazer uso da longa fila dos precatórios públicos.

Em outra tonada, a jurídica, esse dispositivo da Lei $\mathrm{n}^{\circ} 11.079 / 04$ pode sofrer do flagelo da inconstitucionalidade, por burlar os preceitos constitucionais no que tange à execução das dívidas do poder público via sistema de precatórios. ${ }^{70}$

Essa perspectiva é defendida pelo professor Kiyoshi Harada, em célebre parecer:

Não há, portanto, possibilidade jurídica de a receita pública em geral garantir obrigações pecuniárias contraídas pelo poder público em face deste ou daquele particular. Do contrário violados restariam os princípios da impessoalidade e da moralidade, insertos no art. 37 da CF e que são de observância impositiva, nos precisos termos do art. 100 caput da Carta Política $(. . .)^{71}$

\begin{abstract}
Absolutamente inconstitucional o inciso I do art. $8^{\circ}$ da Lei ${ }^{\circ} 11.079 / 04$, que permite a vinculação de receitas públicas, para garantia das obrigações pecuniárias genéricas contraídas pelo Poder Público perante os particulares. Isso é uma verdadeira inversão da ordem pública, que afronta os princípios da moralidade e da impessoalidade, insertos no art. 37 da Constituição Federal, de observância impositiva na forma do seu art. 100, caput. Ironicamente, esse art. $8^{\circ}$ atenta, como vimos, contra o art. 167 , IV da CF, que ele próprio manda observar em seu inciso I, in fine. ${ }^{72}$
\end{abstract}

Acresce a esses argumentos, a violação ao princípio da igualdade, da impessoalidade e da moralidade, como assevera o professor Celso Antônio Bandeira de Mello:

Estado brasileiro em face dos potenciais credores". (Cf. JUSTEN FILHO, Marçal. Curso de Direito Administrativo. $9^{\circ}$ ed. São Paulo: Revista dos Tribunais, 2013, p. 834).

${ }^{69}$ Segue a crítica do professor Celso Antônio Bandeira de Mello, onde vislumbra o instituto das PPPs como um instrumento de proteção exagerada ao capital privado: "Trata-se de instituto controvertido, forjado na Inglaterra, ao tempo da sra. Tatcher, e acolhido entusiasticamente pelo Banco Mundial e pelo Fundo Monetário Nacional no cardápio de recomendações aos subdesenvolvidos. A parceria pública privada que foi jucundamente auspiciada pelo partido governista - outrora comprometido com os interesses da classe trabalhadora, e hoje ponta-de-lança das aspirações dos banqueiros -, constitui-se na crème de la crème do neoliberalismo, pelo seu apaixonado desvelo na proteção do grande capital e das empresas financeiras. Nem mesmo o Governo do Sr. Fernando Cardoso, em despeito de sua álacre submissão aos ditames do FMI, ousou patrociná-la, talvez por uma questão de decoro". (MELLO, Celso Antônio Bandeira de. Curso de direito administrativo. 27 ed. São Paulo: Malheiros Editora, 2010, p. 773).

${ }^{70}$ Constituição Federal. Art. 100. Os pagamentos devidos pelas Fazendas Públicas Federal, Estaduais, Distrital e Municipais, em virtude de sentença judiciária, far-se-ão exclusivamente na ordem cronológica de apresentação dos precatórios e à conta dos créditos respectivos, proibida a designação de casos ou de pessoas nas dotações orçamentárias e nos créditos adicionais abertos para este fim.

${ }^{71}$ HARADA, Kiyoshi. Inconstitucionalidade do Fundo Garantidor das Parcerias Público-Privadas. Art. $8^{\circ}$ da Lei no 11.079/04. Parecer a Comissão de Precatórios da Ordem dos Advogados do Brasil, Seção de São Paulo, p. 07.

${ }^{72}$ HARADA, Kiyoshi. Inconstitucionalidade do Fundo Garantidor das Parcerias Público-Privadas. Art. $8^{\circ}$ da Lei no 11.079/04. Parecer a Comissão de Precatórios da Ordem dos Advogados do Brasil, Seção de São Paulo, p. 08. 
De resto, a utilização de tais fundos em benefício de parceiros privados ou de seus financiadores, se não estivesse constitucionalmente obstada pela razão exposta, estaria embargada por outro obstáculo constitucional. É que, ao privilegiá-los no confronto com todos os restantes credores do Poder Público, ficariam agredidos, à força aberta, o princípio da igualdade, consagrado no art. $5^{\circ}$, caput, bem como os princípios da impessoalidade e da moralidade, impostos pelo art. 37 da Constituição. Com efeito, se o despautério suposto no art. $8^{\circ}$, II, da Lei 11.079 fosse utilizável, ali estaria consagrada uma escandalosa e inconstitucional ofensa ao princípio da igualdade. É que todos os demais credores, inclusive os que se encontram na interminável fila de aguardo dos pagamentos de precatórios atrasados, seriam preteridos em favor de megaempresários, os superprotegidos "parceiros" e seus financiadores. ${ }^{73}$

$\mathrm{Na}$ perspectiva do professor Binenbojm, não se vislumbra contrariedade à norma constitucional $^{74}$ a partir dos seguintes argumentos:

(..) A uma, porque seria legítimo ao Poder Público desafetar determinado bem imóvel de seu patrimônio e dá-lo em garantia de um contrato. A desafetação do bem importa a possibilidade de disposição do bem, o que se pode fazer mediante as formas contratuais admitidas pelo direito. A constituição de uma hipoteca, por exemplo, seria uma forma válida de garantir um contrato de que o Poder Público fosse parte.

A duas, porque a fórmula da constituição de uma entidade de direito privado para funcionar como fundo garantidor é absolutamente legítima e respaldada pelo art. 173, $\S 1^{\circ}$, inciso II, da Carta da República. Nada impede, de fato, que o Poder Público constitua uma empresa pública ou uma sociedade de economia mista (ou uma subsidiária dessas entidades) cujo objeto social seja o de garantir determinados projetos, concebidos no formato de PPP. Trata-se de um aspecto da atividade de fomento, que pode ser desempenhada por pessoas estatais de direito privado. $(. .)^{75}$

$\mathrm{Na}$ defesa pela constitucionalidade, também são os argumentos do professor Alexandre Aragão:

(...) que o art. 165, § $9^{\circ}, \mathrm{II}, \mathrm{CF}$, impõe é que as condições para a instituição e funcionamento de fundos sejam genericamente disciplinadas por lei complementar, não que a criação de cada fundo específico o seja. Essa lei

\footnotetext{
${ }^{73}$ MELLO, Celso Antônio Bandeira de. Curso de direito administrativo. 27 ed. São Paulo: Malheiros Editora, 2010, p. 789.

${ }^{74}$ Também é o pensar do professor Marçal Justen Filho. Cf. JUSTEN FILHO, Marçal. Curso de Direito Administrativo. $9^{\circ}$ ed. São Paulo: Revista dos Tribunais, 2013, p. 834.

75 BINENBOJM, Gustavo. As Parcerias Público-Privadas (PPPs) e a Constituição. Revista Eletrônica de Direito Administrativo Econômico, Salvador, Instituto de Direito Público da Bahia, no 2, maio-jun-jul, 2005. Disponível na Internet: <http:www.direitodoestado.com.br>. Acesso em: 18 de dezembro de 2013, p. 14.
} 
complementar (lei-quadro) já existe; é a Lei no 4.320/64, cujos arts. 71 a 74 se referem apenas à "lei", portanto lei ordinária, para instituir o fundo. ${ }^{7677}$

Quanto ao ponto nodal da violação do art. 100, CF, se considerássemos a criação de qualquer entidade privada da Administração Indireta como desvio de poder legislativo para exclusão do regime de Direito Público de atividade que, constitucionalmente, incumbem primariamente à União, todas elas poderiam ser consideradas inconstitucionais. $(. . .)^{78}$

2.7. Da possibilidade do uso da arbitragem como meio de solução de conflitos no seio das parceiras públicas e privadas

Uma outra inovação trazida ao bojo contratual entre o poder público e o setor privado, no âmbito das parcerias público-privadas, é a possibilidade de solucionar os conflitos via arbitragem, como dispõe o inciso III do art. 11 da Lei no 11.079/04:

III - o emprego dos mecanismos privados de resolução de disputas, inclusive a arbitragem, a ser realizada no Brasil e em língua portuguesa, nos termos da Lei $\mathrm{n}^{\circ}$ 9.307, de 23 de setembro de 1996, para dirimir conflitos decorrentes ou relacionados ao contrato.

É outro fato notório nas práxis dos contratos com o Poder Público, a alta probabilidade de que tal negócio jurídico tenha suas cláusulas apreciadas pelo Poder Judiciário, tendo em vista o descumprimento delas por algum dos partícipes, vindo a solução judicial se "prolongar pela eternidade", em face de toda uma conjuntura sistêmica, o qual não é objeto do trabalho.

O fato é que, pela alta probabilidade do conflito entre os contratantes e da demora em sua solução pela via judicial, tem o custo social e econômico do contrato sobrelevado ${ }^{79}$ o que gera prejuízo a todos os partícipes, seja o poder público, que não tem a obra do hospital

\footnotetext{
${ }^{76}$ ARAGÃO, Alexandre Santos de. As Parcerias Público-Privadas - PPP's no Direito Positivo Brasileiro. Revista Eletrônica de Direito Administrativo Econômico, Salvador, Instituto de Direito Público da Bahia, $\mathrm{n}^{\circ}$ 2, maio-jun-jul, 2005. Disponível na Internet: 〈http:www.direitodoestado.com.br>. Acesso em: 18 de dezembro de 2013, p. 26.

${ }^{77}$ Cf. CARVAlHO FILHO, José dos Santos. Manual de Direito Administrativo. 25 ed. São Paulo: Editora Atlas, 2012, p. 434.

78 ARAGÃO, Alexandre Santos de. As Parcerias Público-Privadas - PPP's no Direito Positivo Brasileiro. Revista Eletrônica de Direito Administrativo Econômico, Salvador, Instituto de Direito Público da Bahia, $\mathrm{n}^{\circ}$ 2, maio-jun-jul, 2005. Disponível na Internet: 〈http:www.direitodoestado.com.br〉. Acesso em: 18 de dezembro de 2013 , p. 27.

79 “Todas essas ineficiências aparecem com mais proeminência nos contratos de grande vulto, sobremodo na fase de construção, principalmente em contratos de tipo Build-Operate-Transfer (BOT), onde os riscos são maiores. Daí, uma combinação deletéria se mostra nessa fase, a saber, incompletude intrínseca, risco: elevados e custos de transação. Nesse último caso, esses custos são consideráveis quando as demandas são judicializadas. Aliás, essa é uma fundamental diferença entre o Sistema judicial brasileiro e o norte-americano, por exemplo. No Brasil, a grande maioria dos conflitos é jurisdicizada. A inoperância e corrupção do judiciário no elevam os custos de transação do sistema de forma exponencial. Há, sem dúvida, uma expectativa racional dos atores durante a elaboração do contrato de que esse problema ocorrerá e parte desses custos de transação serão 'desovados' para má execução contratual pela troca de material por produtos de má qualidade”. (NÓBREGA, Marcos. Análise econômica do Direito Administrativo. IN: TIMM, Luciano (org.). Direito e economia no Brasil. São Paulo. Atlas: 2011, p. 410).
} 
acabada, o serviço público prestado; seja a entidade privada, que pela simples demanda judicial já tem o seu custo e com a demora da solução pode levar um grande espaço de tempo para receber a sua devida contraprestação.

Daí a figura da arbitragem, ou seja, a possibilidade de uma solução ao conflito de forma mais rápida feita um juiz arbitral de conhecimento técnico específico das nuances dessa espécie contratual.

É bom advertir que o magistrado, provavelmente, não terá o conhecimento multidisciplinar para entender toda a complexidade de um contrato administrativo e, principalmente, se o contrato for de uma parceria público-privada. No âmbito do juízo arbitral, ter-se-á um arbitro que atenda a essas especificidades da demanda. ${ }^{80}$

A figura da arbitragem, nessa seara de contratos administrativos, constitui outro fator de diminuição de risco e custo ao contrato. ${ }^{81}$

Não se perfilha com a corrente que não concebe o instituto da arbitragem para a composição de litígios, no que refere a contratos administrativos, sob a tese de que violaria a pedra angular do princípio da indisponibilidade do interesse público. ${ }^{82}$

\footnotetext{
80 “Um terceiro ponto relevante encontra-se no alto grau de especialização dos árbitros. Ao contrário dos juízes togados, por expressa previsão legal o juiz arbitral não precisa ser necessariamente, um profissional com graduação em Direito. Pode possuir qualquer formação técnica ou universitária, o que é uma vantagem para as partes. Com efeito, em um conflito envolvendo um aspecto de alta complexidade tecnológica, é preferível obter a solução a partir de um profissional do ramo, com experiência para decifrar os termos técnicos e medir as consequências de suas posições". (OLIVEIRA, Luís Fernando Lima de. O juízo de Salomão: eficiência, validade e limites do uso da arbitragem nas concessões públicas brasileiras. IN: Revista brasileira de direito administrativo e regulatório. São Paulo: Editora MP, V. 4, 2011, p. 144.)

81 “(...) Em um juízo de proporcionalidade entre benefícios (custos mais baixos em contratos administrativos) e riscos (eventuais e suscetíveis de correção pontual em casos de vícios formais ou fraude, nos casos previstos no art. 32 da Lei $n^{\circ}$ 9.307/96), a balança do custo-benefício me parece claramente pender em favor da convenção da cláusula compromissória". (BINENBOJM, Gustavo. As Parcerias Público-Privadas (PPPs) e a Constituição. Revista Eletrônica de Direito Administrativo Econômico, Salvador, Instituto de Direito Público da Bahia, $\mathrm{n}^{\circ}$ 2, maio-jun-jul, 2005. Disponível na Internet: 〈http:www.direitodoestado.com.br〉. Acesso em: 18 de dezembro de 2013, p. 17). “(...) Nesta modalidade contratual, devem ser estabelecidos mecanismos de fortalecimentos das relações de confiança entre as partes, que estimulem o cumprimento dos termos acordados, como é o caso da arbitragem". (OLIVEIRA, Luís Fernando Lima de. O juízo de Salomão: eficiência, validade e limites do uso da arbitragem nas concessões públicas brasileiras. IN: Revista brasileira de direito administrativo e regulatório. São Paulo: Editora MP, V. 4, 2011, p. 146.)

82 "Não é aceitável perante a Constituição que particulares, árbitros, como suposto no art. 11, III, possam solver contendas nas quais estejam em causa interesses concernentes a serviços públicos, nas quais não se constituem em bens disponíveis, mas indisponíveis, coisas extra commercium. Tudo que diz respeito ao serviço público, portanto - condições de prestação, instrumentos jurídicos compostos em vista desse desiderato, recursos necessários para bem desempenhá-los, comprometimento destes mesmos recursos -, é questão que ultrapassa o âmbito decisório de particulares (...). Envolve interesses de elevada estatura, pertinentes à Sociedade como um todo; e, bem por isto, quando suscitar algum quadro conflitivo entre partes, só pode ser soluto pelo Poder Judiciário. Permitir que simples árbitros disponham sobre matéria litigiosa que circunde um serviço público e que esteja, dessarte, com ele imbricada ofenderia o papel constitucional do serviço público e a própria dignidade que o envolve". (MELLO, Celso Antônio Bandeira de. Curso de direito administrativo. 27 ed. São Paulo: Malheiros Editora, 2010, p. 789).
} 
Nas palavras do professor Marçal Justen Filho, esse argumento não procede tendo em vista que geraria uma séria contradição, pois se a figura da arbitragem comprometeria a normatividade do princípio da indisponibilidade do interesse público, de tal sorte, não poderse-ia admitir a figura dos contratos administrativos.

Logo, o argumento de que a arbitragem nos contratos administrativos é inadmissível porque o interesse público é indisponível conduz a um impasse insuperável. Se o interesse público é indisponível ao ponto de excluir a arbitragem, então seria indisponível igualmente para o efeito de produzir contratação administrativa. Assim como a Administração Pública não disporia de competência para criar a obrigação vinculante relativamente ao modo de composição do litígio, também não seria investido do poder para criar qualquer obrigação vinculante por meio consensual. ${ }^{83}$

Deve-se lembrar que, a figura dos princípios não pode ser interpretada de forma absoluta. Assim, não se procede a ilação de que toda a atividade da administração pública se estar a tratar de bens e direitos indisponíveis. ${ }^{84}$

\section{CONSIDERAÇÕES FINAIS}

No bojo do conteúdo apresentado, afere-se que as parcerias públicas e privadas, em sua execução perfeita, promoveriam a diminuição das falhas de mercado e das falhas governamentais, ${ }^{85}$ constituindo-se um misto do melhor da coisa pública com o melhor do setor privado.

Assim, as parcerias públicas e privadas surgem em razão de obras e serviços públicos gratuitos ou quase gratuitos, para os usuários, em que o setor privado constrói e gerencia, tendo a sua despesa amortizada ou remunerada pelo setor público. ${ }^{86}$

\footnotetext{
${ }^{83}$ JUSTEN FILHO, Marçal. Curso de Direito Administrativo. $9^{\circ}$ ed. São Paulo: Revista dos Tribunais, 2013, p. 822.

84 "Mais especificamente, existem questões de cunho meramente patrimonial. A Administração Pública deixou de pagar uma prestação contratualmente prevista sob o fundamento da infração às especificações técnicas contratuais, essa é uma questão patrimonial, de natureza disponível. O conflito entre Administração Pública e particular, envolvendo a interpretação das cláusulas contratuais, é uma questão disponível, precisamente porque a cláusula a ser interpretada foi criada pela vontade disponível das partes. A disputa sobre a configuração da quebra da equação econômico-financeira é uma questão disponível, já que se relaciona à controvérsia sobre os fatos verificados no mundo real e seus efeitos sobre a relação original em direitos e obrigações assumidos pelas partes". (JUSTEN FILHO, Marçal. Curso de Direito Administrativo. $9^{\circ}$ ed. São Paulo: Revista dos Tribunais, 2013, p. 822).

${ }^{85}$ Cf. NÓBREGA, Marcos. Direito da Infraestrutura. São Paulo, Quartier Latin, 2011, p. 72.

${ }^{86}$ Cf. ARAGÃO, Alexandre Santos de. As Parcerias Público-Privadas - PPP's no Direito Positivo Brasileiro.

Revista Eletrônica de Direito Administrativo Econômico, Salvador, Instituto de Direito Público da Bahia, ${ }^{\circ}$ 2, maio-jun-jul, 2005. Disponível na Internet: 〈http:www.direitodoestado.com.br〉. Acesso em: 18 de dezembro de 2013, p. 04.
} 
Tal modelagem contratual, pelas suas peculiaridades inovadoras, frente a um direito administrativo clássico, gera as mais diversas controvérsias, bem como a necessidade do aprofundamento em seu estudo.

Nesse plexo de características distintivas, que possui essa formatação de contrato administrativo, sobreleva uma modalidade de delegação, na qual, a entidade publica remunera total ou parcialmente a entidade privada exploradora da atividade; constitui um sistema de compartilhamento dos riscos, não sendo mais essa suportada, tão somente, pela parceira privada; forma-se um feixe de garantias aos investimentos da entidade privada, com destaque a criação de um fundo garantidor, a qual tem personalidade privada, por meio da desafetação de bens públicos, com o fito de evitar o sistema de pagamento via precatórios; possibilita-se a solução de conflitos entre os parceiros por meio do uso da arbitragem, o que permite uma solução a lide de forma mais célere e dado por alguém com expertise na matéria; e por fim, direciona-se para uma modelagem contratual, em que as obrigações constituídas sejam feitas com responsabilidade fiscal e sustentabilidade financeira.

É certo que, se esse instrumento for manejado dentro dos termos éticos, ter-se-á um contrato capaz de propiciar a resolução de conflitos e absorção de choques externos. ${ }^{87}$

Destarte, contratos com esses atributos constituiriam uma poderosa ferramenta para a renovação do complexo de infraestrutura do Brasil e consequente expansão do desenvolvimento econômico, granjeando, assim, a efetivação de diversos direitos fundamentais do carente cidadão brasileiro.

\section{REFERÊNCIAS}

ALVAREnGA, José Eduardo. Parcerias Público-Privadas: breves comentários. Revista Eletrônica de Direito Administrativo Econômico, Salvador, Instituto de Direito Público da Bahia, ${ }^{\circ}$ 2, maio-jun-jul, 2005. Disponível na Internet: 〈http:www.direitodoestado.com.br〉. Acesso em: 18 de dezembro de 2013.

ARAGÃO, Alexandre Santos de. As Parcerias Público-Privadas - PPP's no Direito Positivo Brasileiro. Revista Eletrônica de Direito Administrativo Econômico, Salvador, Instituto de Direito Público da Bahia, $\mathrm{n}^{\circ}$ 2, maio-jun-jul, 2005. Disponível na Internet: <http:www.direitodoestado.com.br>. Acesso em: 18 de dezembro de 2013.

AZEVEDO, Maria Eduarda. Parcerias Público-Privadas: instrumento de uma nova governança pública. 2008. Tese para obtenção do título de Doutora em Direito - Faculdade de Direito de Lisboa.

BINENBOJM, Gustavo. As Parcerias Público-Privadas (PPPs) e a Constituição. Revista Eletrônica de Direito Administrativo Econômico, Salvador, Instituto de Direito Público da

\footnotetext{
${ }^{87}$ Cf. NÓBREGA, Marcos. Contratos incompletos e infraestrutura: contratos administrativos, concessões de serviço público e PPPs. IN: Revista brasileira de direito administrativo e regulatório. São Paulo: Editora MP, V. 1, 2010, p. 140.
} 
Bahia, $\mathrm{n}^{\mathbf{o}}$ 2, maio-jun-jul, 2005. Disponível na Internet: 〈http:www.direitodoestado.com.br〉. Acesso em: 18 de dezembro de 2013.

CARVAlHO FILHO, José dos Santos. Manual de Direito Administrativo. $25^{\circ}$ ed. São Paulo: Editora Atlas, 2012.

CASTRO JR, Osvaldo Agripino de. Breves considerações sobre o direito e desenvolvimento e sua relevância para a consolidação da justiça social e da cidadania no Brasil. Arquivo digital.

DI PIETRO, Maria Sylvia Zanella. Direito Administrativo. 24º ed. São Paulo: Editora Atlas, 2011.

Editora Atlas, 2012.

Parcerias na administração pública. $9^{\circ}$ ed. São Paulo:

GROTTI, Dinora Adelaide Musetti. Parcerias na administração pública. IN: Revista brasileira de direito administrativo e regulatório. São Paulo: Editora MP, V. 5, 2012.

HARADA, Kiyoshi. Inconstitucionalidade do Fundo Garantidor das Parcerias PúblicoPrivadas. Art. $8^{\circ}$ da Lei $n^{\circ} 11.079 / 04$. Parecer a Comissão de Precatórios da Ordem dos Advogados do Brasil, Seção de São Paulo.

JUSTEN FILHO, Marçal. Curso de Direito Administrativo. $9^{\circ}$ ed. São Paulo: Revista dos Tribunais, 2013.

MELLO, Celso Antônio Bandeira de. Curso de direito administrativo. $27^{\circ}$ ed. São Paulo: Malheiros Editora, 2010.

MODESTO, Paulo. Reforma do Estado, Formas de Prestação de Serviços ao Público e Parcerias Público-Privadas: demarcando as fronteiras dos conceitos de serviço público, serviços de relevância pública e serviços de exploração econômica para as parcerias públicoprivadas. Revista Eletrônica de Direito Administrativo Econômico, Salvador, Instituto de Direito Público da Bahia, $\mathrm{n}^{\circ}$ 2, maio-jun-jul, 2005. Disponível na Internet: <http:www.direitodoestado.com.br>. Acesso em: 18 de dezembro de 2013.

NÓBREGA, Marcos. Análise econômica do Direito Administrativo. IN: TIMM, Luciano (org.). Direito e economia no Brasil. São Paulo. Atlas: 2011.

Marcos. Contratos incompletos e infraestrutura: contratos administrativos, concessões de serviço público e PPPs. IN: Revista brasileira de direito administrativo e regulatório. São Paulo: Editora MP, V. 1, 2010.

, Marcos. Direito da Infraestrutura. São Paulo, Quartier Latin, 2011.

NUNES, Thiago Mesquita. Da alocação de riscos enquanto fundamento subjacente ao equilíbrio econômico-financeiro dos contratos administrativos. IN: Revista brasileira de direito administrativo e regulatório. São Paulo: Editora MP, V. 5, 2012.

OLIVEIRA, Luís Fernando Lima de. O juízo de Salomão: eficiência, validade e limites do uso da arbitragem nas concessões públicas brasileiras. IN: Revista brasileira de direito administrativo e regulatório. São Paulo: Editora MP, V. 4, 2011.

SILVA, Roberta Cruz da. Entre o endeusamento e a descrença: a perigosa visão dicotômica sobre o contrato de parceria pública-privada na seara administrativa brasileira. IN: Revista brasileira de direito administrativo e regulatório. São Paulo: Editora MP, V. 4, 2011.

United Nations Economic Comission for Europe. Guidebook on promoting good governance in public-private partnerships. Geneve, 2008. Disponível em: <http://www.unece.org/fileadmin/DAM/ceci/publications/ppp.pdf>. Acesso em: $20 \mathrm{de}$ dezembro de 2013. 